\title{
Germination potential of Hymenaea courbaril L. in different maturation stages
}

\section{Potencial germinativo de sementes de Hymenaea courbaril L. em diferentes estádios de maturação}

\author{
Hugo Roldi Guariz ${ }^{1 *}$; Halley Caixeta de Oliveira2; Huezer Viganô Sperandio3; \\ Jean Carlo Baudraz de Paula1; Gabriel Danilo Shimizu'; Walter Aparecido \\ Ribeiro Junior ${ }^{1}$
}

\section{Highlights}

Jatobá seeds at different maturation stages are able to germinate satisfactorily. Green seeds are recommended for planting and seedling production. Mature scarified seeds are capable of generating vigorous seedlings.

\section{Abstract}

The production of quality forest seedlings in large quantities is essential for the restoration of environments that have been deforested and degraded. However, obtaining seeds with high vigor is a challenge for several tree species native to Brazil. The objective of this work was to verify the germination potential of jatobá-damata seeds at different stages of maturation, in order to favor the production of seedlings of this species in nurseries. The seeds were extracted from green and ripe fruits detached from the mother plant and ripe fruits collected from the ground. The germination percentage, average germination time, emergence speed index, average speed, relative frequency, leaf area of the seedling, and length of the aerial part and root were measured. The planting was carried out with mechanically scarified and intact seeds from each maturation group. The results indicated that non-scarified green seeds can be used for planting and seedling production, as they do not require pre-germination treatment and have a favorable germination percentage (79\%). Fruit seeds harvested from the ground, on the other hand, needed a method to overcome integumentary dormancy, such as mechanical scarification, obtaining a germination rate of $85 \%$. The seeds of ripe fruits harvested in the matrix showed greater vigor, with a higher percentage of germination (96 to $100 \%$ ), a higher emergence speed index, shorter average germination time, and seedlings with greater leaf area and greater length of shoot.

Key words: Jatobá-da-mata. Germination. Vigor. Mechanical scarification.

1 Students of the PhD of the Postgraduate Program in Agronomy, Universidade Estadual de Londrina, UEL, Londrina, PR, Brazil. E-mail: hroldig@hotmail.com; shimizu@uel.br; jc_baudraz@live.com; junior_agro40@hotmail.com

2 Prof. Dr., Department of Animal and Plant Biology, Universidade Estadual de Londrina, UEL, Londrina, PR, Brazil. E-mail: halley@uel.br

${ }^{3}$ Student of the PhD of the Postgraduate Program in Forest Science, Universidade Federal dos Vales do Jequitinhonha e Mucuri, UFVJM, Diamantina, MG, Brazil. E-mail: huezer@gmail.com

* Author for correspondence

Received: May 24, 2021 - Approved: Aug. 24, 2021 


\section{Resumo}

A produção de mudas florestais com qualidade e em quantidade é essencial para a restauração de ambientes outrora desmatados e degradados. Todavia, a obtenção de sementes com alto vigor é um desafio para diversas espécies arbóreas nativas do Brasil. O objetivo deste trabalho foi verificar o potencial germinativo de sementes de jatobá-da-mata em diferentes estádios de maturação, de modo a favorecer a produção de mudas dessa espécie em viveiros. As sementes foram extraídas de frutos verdes e maduros destacados da planta mãe e frutos maduros coletados no chão. Foram mensurados o percentual de germinação, o tempo médio de germinação, o índice de velocidade de emergência, a velocidade média, a frequência relativa, área foliar da plântula e comprimento de parte aérea e raiz. A semeadura foi realizada com sementes escarificadas mecanicamente e intactas de cada grupo de maturação. Os resultados indicaram que as sementes verdes não escarificadas podem ser utilizadas para semeadura e produção de mudas, por dispensarem tratamento pré-germinativo e possuírem percentual de germinação favorável (79\%). Já as sementes de frutos colhidos no chão necessitaram de um método para superar a dormência tegumentar, como a escarificação mecânica, obtendo a germinação de 85\%. As sementes de frutos maduros colhidos na matriz apresentaram maior vigor, com maior percentual de germinação (96 a 100\%), maior índice de velocidade de emergência, menor tempo médio de germinação, plântulas com maior área foliar e maior comprimento de parte aérea.

Palavras-chave: Jatobá-da-mata. Germinação. Vigor. Escarificação mecânica.

\section{Introduction}

The production of quality forest seedlings, in large quantities, is essential in the preservation of forests and maintenance of the environment, for use in the recovery of degraded areas, formation of legal reserves and permanent preservation areas, urban afforestation, and formation of ecological corridors. Although it is pointed out that $66.3 \%$ of the area in Brazil is covered by forest (Gazzoni, Cattelan, \& Nogueira, 2019), deforestation rates in all biomes are increasing. As detailed in a study by Global Forest Watch, considering the sum of all biomes, Brazil was the country that lost the most trees in 2018 worldwide, approximately 1.3 million hectares of primary forests (Weisse \& Goldman, 2019). According to The Economist Newspaper (2019), forests still provide a livelihood for 1.5 billion people and a buffer against climate change. However, as reported by Loose and Balbé (2020), the fragile conception of development that has become hegemonic is mainly based on economic growth, in an unlimited perspective, leaving aside numerous aspects of human well-being and ignoring the fact that this path is unsustainable, as already known for some resources (such as tropical forests).

In this context, the creation of reforestation strategies, the choice of suitable species, and the production of seedlings that, in some way, not only contribute to the conservation and restoration of natural environments, but also serve as models that are replicable, become a priority in actions of this magnitude. In addition, knowledge of the fruit maturation process, as an indicator of the harvest point, is essential for obtaining seeds of high physiological quality, and should be considered in forest seed production programs. 
Among the species that stand out in reforestation for projects of recovery or restoration of degraded areas, we can list the Jatobá or Jatobá-da-Mata (Hymenaea courbaril L.), a species found throughout the country, which is the most popular and important among the species of the genus, and is present as vulnerable on the list of endangered species, due to logging and forest fragmentation (Alonso et al., 2014). According to Lorenzi (2020), since it is a plant that is not very demanding in terms of fertility and soil moisture, it should not be lacking in the composition of heterogeneous reforestations and in the afforestation of parks and large gardens. Associated with these characteristics, Jatobá is a climax plant (reaches the forest canopy, being the last stage of ecological succession) (Regnier, 2020), heliophyte (needs exposure to light for its full development, when adult), or sciophyte (develops in a shaded environment in its young phase), and selective xerophyte (it develops in dry environments) (Lorenzi, 2020).

The formation of Jatobá seedlings is essentially seminal and it would be beneficial to investigate cultivation techniques used in the seedling production process, especially in the stages of collection and processing of fruits and seeds. For satisfactory and efficient germination, the handling of Jatobá fruits and seeds requires the fruit to be opened with the aid of a hatchet or hammer, followed by extraction, washing in running water, drying in the shade, and mechanical scarification of the seeds, steps which represent a lengthy and complicated process.
Regarding the performance of Jatobáda-Mata seeds, there are no reports on the maturation stage of the fruits collected for the production of seedlings and germination analysis. In view of this, it is still necessary to define the appropriate time for collection during the maturation of Jatobá seeds, in order to facilitate and accelerate the production of seedlings in nurseries. Thus, the objective of this work was to verify the germination potential of Jatobá seeds at different maturation stages.

\section{Material and Methods}

The fruits were harvested from three matrix trees 10-12 $\mathrm{m}$ high, located in a mixed orchard of fruits and native trees, in the municipality of Primeiro de Maio/ PR (22053'14"S, 5056'42"W). The region's climate is classified according to Köppen as humid subtropical $\mathrm{Cfa}$, with an average annual temperature of $22.1^{\circ} \mathrm{C}$ and an average annual precipitation of $1290 \mathrm{~mm}$. The fruit maturation stages were based on the epicarp coloration, according to the MUNSELL color chart (Munsell, 1952), resulting in the classifications 10R 3/6, 5GY 4/6, and 7.5YR 5/4.

The fruits were manually collected with the aid of a ladder and aerial pruning scissors, and classified into three stages of maturation, namely: ripe fruits collected from the matrix, unripe fruits collected from the matrix, and ripe fruits collected from the ground, as shown in Figure 1. The unripe fruits had completely green skin, with total visual growth achieved, and whitish-green arils. 

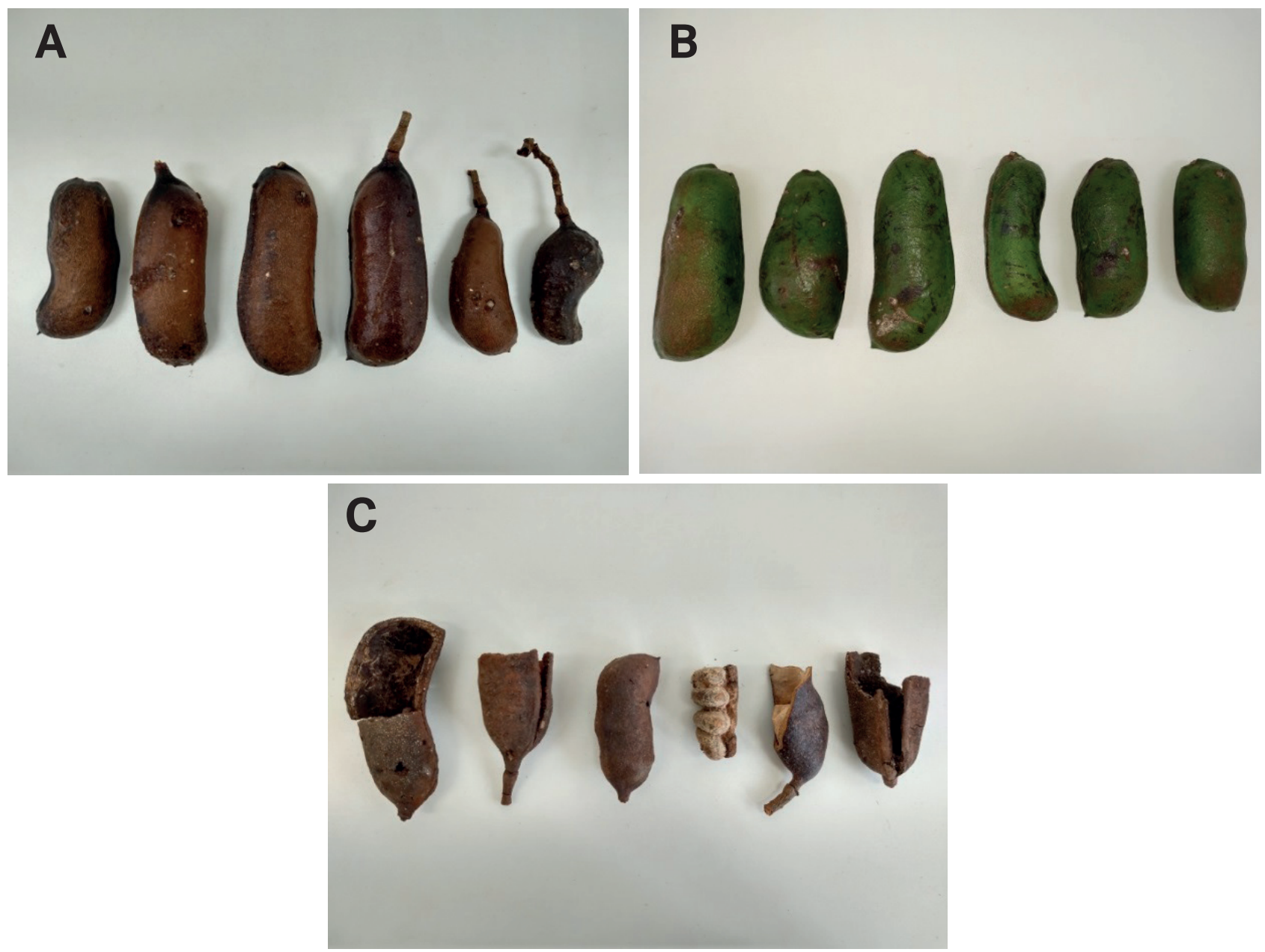

Figure 1. Morphological and maturation differentiation of Jatobá fruits. Ripe fruits collected from the matrix (A), unripe fruits collected from the matrix $(B)$, and ripe fruits collected from the ground (C).

The seeds were removed from the fruits using hammers, manually separated from the farinaceous aril and sown in 1.00 $\times 1.00 \times 0.60 \mathrm{~m}$ boxes, with sand, in the nursery belonging to LABRE - Laboratory of Biodiversity and Restoration of Ecosystems of the State University of Londrina. Prior to sowing, the seeds of the three maturation groups were submitted to the mechanical scarification procedure by means of a grinder coupled to an electric drill, breaking the integument on the opposite side of the hilum, while keeping the seed to be sown intact. Seed separation, scarification, and sowing occurred successively and immediately, without intervals. The moisture content of the seeds was determined as recommended in the Seed Analysis Rules (Ministério da Agricultura, Pecuária e Abastecimento [MAPA], 2009).

The experiment was conducted in a completely randomized design, in a $3 \times 2$ factorial scheme, in which the first factor is represented by the stage of fruit maturation (ripe fruits picked from the matrix, ripe fruits 
collected from the ground, and unripe fruits collected from the matrix) and the second factor is represented by scarification (with and without), totaling six treatments. Four replications were used, with 20 seeds each. Data were checked for normality by the Shapiro-Wilk test, and homoscedasticity by the Bartlett test, and submitted to analysis of variance (ANAVA) at the 5\% probability level. Means were compared by the Tukey test at $5 \%$ significance. All analyses were performed using R software.

The experiment was carried out for 50 days, in January and February 2020, and the seeds were considered germinated when the plumular hook was fully immersed in sand, (which was the only substrate used). At the end of the test, from the daily data on the number of emerged seeds, the following variables were calculated:

1 - \% of Emergence (E), calculated using the formula of Labouriau and Valadares (1976):

$$
E=(N / A) \times 100
$$

where: $N=$ number of germinated seeds at the end of the test; $A=$ total number of seeds placed to germinate;

2 - Emergence speed index (ESI), calculated by Maguire (1962) formula:

$$
\mathrm{ESI}=\mathrm{E} 1 / / \mathrm{N} 1+\mathrm{E} 2 / \mathrm{N} 2+\ldots+\mathrm{En} / \mathrm{Nn}
$$

Where: $\mathrm{ESI}=$ emergence speed index; E1, E2, $E n=$ number of seeds germinated in the first, second, and final count; N1, N2, Nn = number of sowing days in the first, second, and final count.

3 - Average emergence time (t) in days, calculated by the formula (Ferreira \& Borghetti, 2013):

$$
\mathrm{t}=(\Sigma \mathrm{ni} \times \mathrm{ti}) / \Sigma \mathrm{ni}
$$

where: $\mathrm{ni}=$ number of germinated seeds per day; ti = incubation time;

4 - Average emergence speed (AES) in days, calculated by the formula (Ferreira \& Borghetti, 2013):

$$
\mathrm{AES}=1 / \mathrm{t}
$$

where: $\mathrm{t}=$ mean germination time. The AES is another way to quantify the germination kinetics, being simply the inverse of the average germination time.

5 - Relative Germination Frequency, in percentage, according to the formula proposed by Labouriau and Valadares (1976):

$$
F r=\frac{n i}{\left(\sum n i\right)}
$$

where: $\mathrm{Fr}=$ relative frequency of germination; $\mathrm{ni}=$ number of germinated seeds per day; $\Sigma \mathrm{ni}$ $=$ total number of germinated seeds;

For the morphological determinations, 50 days after sowing, the following were measured: (1) the length of the root and the length of the aerial part, with the aid of a ruler graduated in millimeters. The measurement was made from the hypocotyl to the main root cap and from the hypocotyl to the base of the apical meristem, respectively, and (2) the leaf area, which was determined with the aid of a portable gauge (LI-COR Biosciences, Lincoln, USA), model LI-3000C, coupled to a mat where the detached leaves were inserted and the area was determined when passing through the measuring chamber. Ten plants were measured, randomly chosen per treatment, and the means were analyzed by the Tukey test at $5 \%$ significance. 


\section{Results and Discussion}

A large variation in fruit size was recorded for the population of Jatobá-daMata, as was also seen by Pereira, Giraldelli, Laura and Souza (2011) and Santos et al. (2019) in H. stigonocarpa var. stigonocarpa showing great variability in relation to fruit size, number of seeds per fruit, and seed mass. Seed moisture content was $6.4 \%$ for mature seeds collected from the ground, $7 \%$ for mature seeds collected from the matrix, and $46.5 \%$ for green seeds collected from the matrix.

Fruit color and moisture content were used as parameters to prescribe the seed maturation stage, since most fruits, such as Jatobá, present color changes during the development process, especially in the bark, due to the degradation of chlorophyll and the synthesis of pigments such as carotenoids and anthocyanins (Barbosa, Rodrigues, Barbério, \& Araujo, 2015; Duarte, Paula, Ferreira, \& Nogueira, 2016). The size of the seeds also changed according to the evolution of the maturation process (Figure 2), due to the dehydration resulting from this process (N. M. Carvalho \& Nakagawa, 2012). Thus, the size of the Jatobá seeds significantly reduced and their color changed, becoming smaller, darker, and clearly harder and stiffer when compared to green seeds (Figure 2).

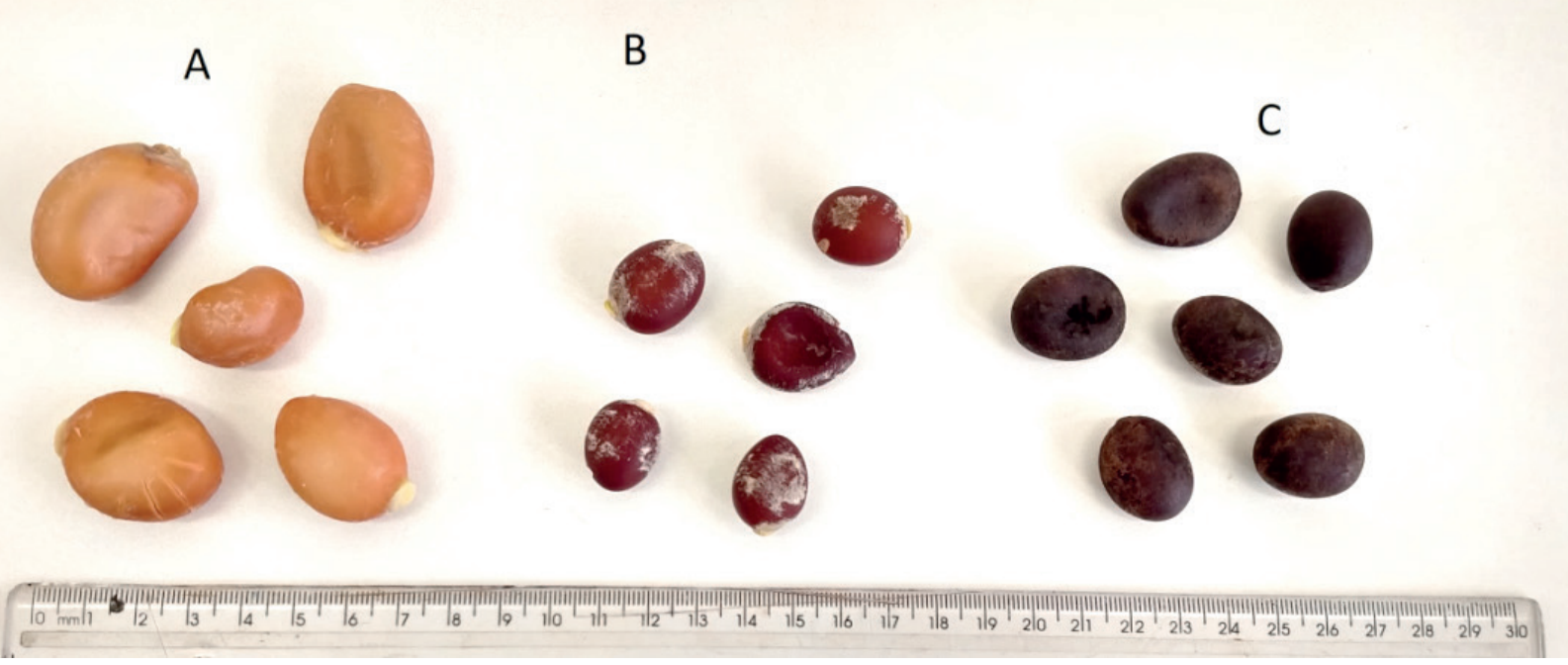

Figure 2. Variation in seed size according to the degree of maturity of the fruits., A - Unripe fruits; B - Ripe fruits collected from the matrix; C - Fruits and seeds harvested from the ground.

Popinigis (1985) pointed out that the seed size increases gradually, from fertilization until reaching the maximum, when it still has a relatively high moisture content and, after reaching the maximum, the size of the seeds decreases, as it loses water. Marcos (2015) reported that, with the intensification of the transfer of reserves from the plant to the seeds, there is a progressive increase in size, in terms of thickness, so that the maximum size is reached approximately halfway through the period of dry matter accumulation, and 
then there is a reduction in size, with variable intensity, which is more evident in legumes, such as soybeans and Jatobá.

The results for percentage of emergence indicated that, in all maturation stages, seeds able to germinate were obtained. Figure 3 shows that for the percentage of emergence (E) the highest values were for ripe fruits harvested from the matrix, regardless of whether or not there was pre-germination treatment, although there were no significant differences for treatment 3 (ripe fruit picked from the ground under scarification) and for treatment 6 (non-scarified seeds of unripe fruits), whose treatments showed $\mathrm{E}$ averages above $79 \%$. The lowest values ( $E<34 \%$ ) were observed in treatments 4 and 5 (scarified seeds of green fruits and non-scarified seeds collected from the ground). In the latter case, the fruit ripening point had been exceeded, so that the seeds had begun to lose their vigor due to deterioration arising from environmental factors, confirming previous data that excessive fruit maturation can be harmful to seed quality (Castro, Bradford, \& Hilhorst, 2004). In addition, fruits in contact with the soil may have increased water content, which, under unfavorable conditions, leads to the beginning of consumption of reserves without germination, affecting the entire germination potential (Nogueira \& Medeiros, 2007; Mojena \& Barreto, 2021).

The highest values of $E$ for treatments 1 and 2 (96 and 100\%) are justified by the fact that the seeds have greater germination potential and vigor, with minimal deterioration, maintaining active tissues and functional metabolism, which, according to Barbosa et al. (2015), marks the determination of the physiological maturity point of the seed. It is also noteworthy that the quality of the seeds is greatly affected when the harvest is performed before they reach physiological maturity or after this stage, as observed in the current work, for the percentage of emergence of seeds harvested from the ground without mechanical scarification intervention, which had the lowest value, as also reported by Pagliarini, Castilho, Nasser and Alves (2016).

For Costa, Bruno, Souza and Lima (2001), the highest percentages of emergence for treatments 1 and 2 are related to the endocarp, which, at this stage, is less lignified, a fact that does not occur in the same way with endocarps of fruits with advanced maturation, due to the difficulty of water penetration through its layers. This fact was also pointed out by Müller, Gibbert, Binotto, Kaiser and Bortolini (2016), with Peltophorum dubium, where percentage of germination was lower for seeds extracted from fully ripe fruits, with integument restriction to the entry of water inside the seed (18\%), and higher for seeds in the maturation phase (43\%).

Mechanical scarification resulted in a high percentage of emergence (treatments 1 and 3). This process allowed the entry of water and oxygen, in addition to favoring the action of hydrolytic enzymes that act with the activation of protein synthesis, enabling the mobilization of reserves from the germination process, as seen by Santos et al. (2019), who obtained $93 \%$ seed germination from $H$. courbaril when subjected to mechanical scarification. This was also seen by other authors, such as Coelho and Ribeiro (2018), above 93\%, Cabral, Castilho and Pagliarini (2015), above 86\%, Sampaio et al. (2015), with $84 \%$, Souza et al. (2015), above $80 \%$, and by Silva and Cesarino (2016) with 69.2\%. 
A)

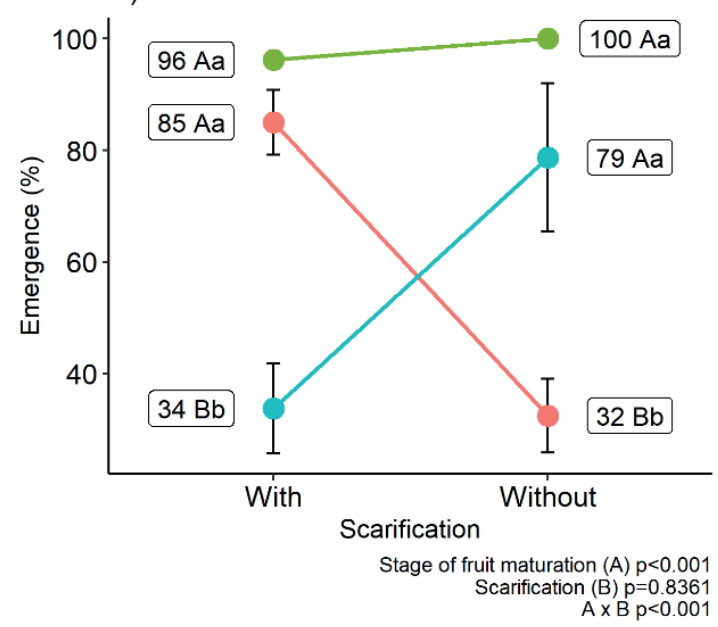

C)

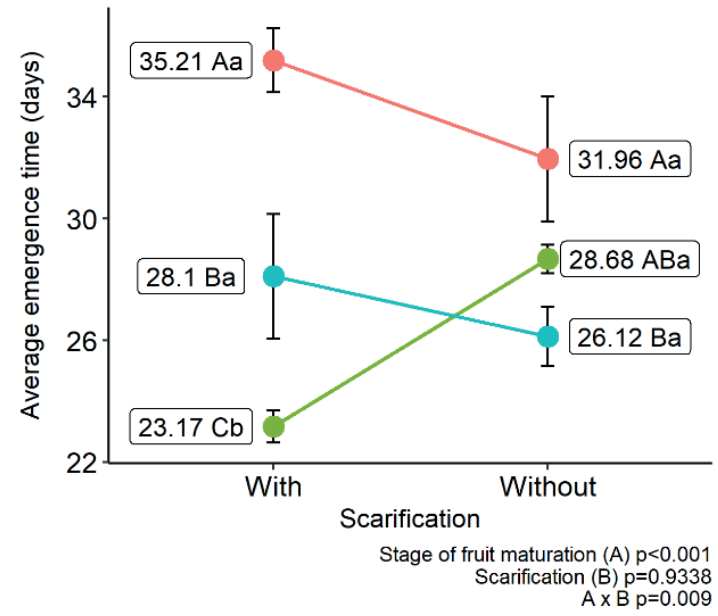

B)

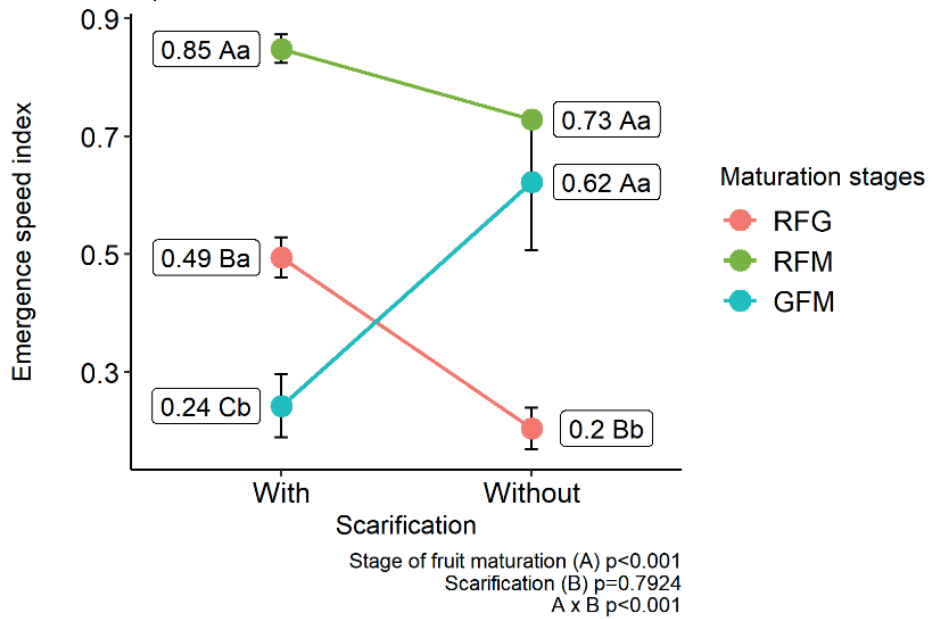

D)

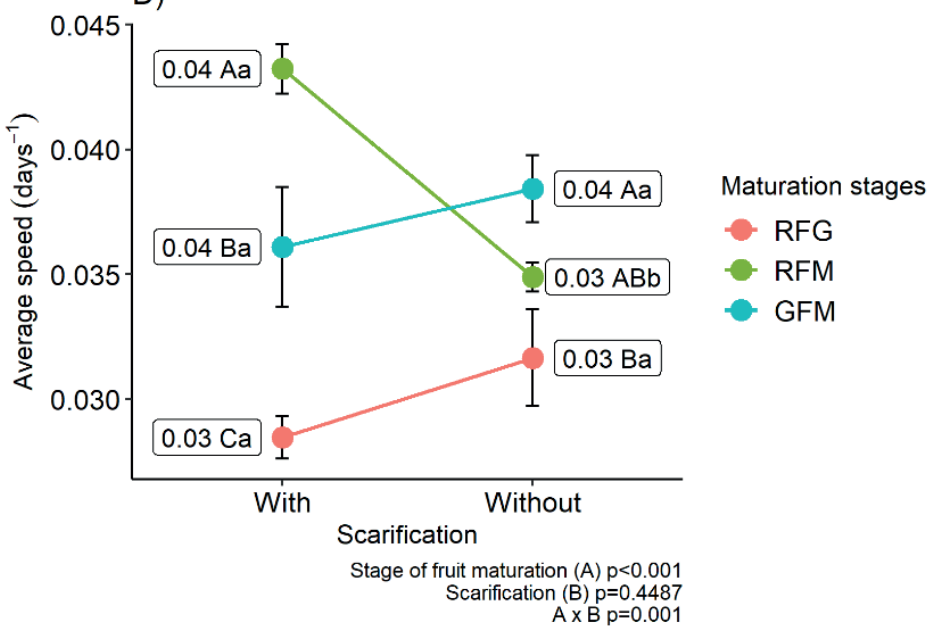

Figure 3. Emergence percentage (E), emergence speed index1 (ESI), average emergence time (t), average speed $(\mathrm{v})$ of $H$. courbaril seeds of different maturation stages.

* Means followed by letters of the same lowercase letter horizontally and uppercase vertically do not differ, according to the Tukey test at 5\%. ${ }^{1}$ data transformed. Where: RFM - Ripe fruits harvested from the matrix (treatments 1 and 2), RFG - Ripe fruits collected from the ground (treatments 3 and 4), GFM -Green fruits collected from the matrix (treatments 5 and 6). Germination CV $=20.54 \%$, ESI $\mathrm{CV}=12.7 \%$, t $C V=9.4 \%$, and $v \mathrm{CV}=8.38 \%$.

For Jatobá, it is necessary to open the fruit with the aid of a hatchet or hammer, followed by separation of the seeds, washing in running water and drying in the shade (Souza et al., 2015), with mechanical scarification of the seeds being more advantageous, as it is less expensive, safer and more convenient, however, this process must be performed with caution so as not to damage the embryo (Nascimento \& Oliveira, 1999), showing efficiency in overcoming the tegumentary dormancy of Jatobá seeds.

Intact green seeds (treatment 6) demonstrated $79 \%$ emergence, not differing from the other treatments with a 
high percentage of emergence (treatments 2, 1, and 3). According to N. M. Carvalho and Nakagawa (2000), seeds that are not completely mature can germinate, however, they result in less vigorous seedlings than those resulting from the germination of seeds that have reached physiological maturity. Also according to Marcos (2015), seeds in early stages of maturation can germinate, as they already have their structures formed, that is, the embryo is already morphologically formed. The lower $E$ value attributed to scarified green seeds (34\%) is due to the mechanical damage caused to the seed, since at this stage the seeds do not have a completely formed integument, with the absence of rigidity and protection characteristics, as well as tissues in formation, so that mechanical intervention generates a decrease in the physiological potential of the seed, affecting the percentage and speed of seedling emergence.

Green seeds with germination capacity to form normal seedlings were also observed for the cultures of Carica papaya (A. W. P. Lopes, Seleguini, Boliani, \& Correa, 2009), for lauraceous such as Ocotea porosa, 0. odorífera, and O. puberula (Hirano \& Possamai, 2008), and for Physalis angulata (Carvalho, Oliveira d'Angelo, Scariot, Saes, \& Cuquel, 2014). In addition, some works pointed out species in which green seeds did not result in a satisfactory germination percentage when different stages of maturation were analyzed, as mentioned by (Costa et al., 2001) in seeds of Spondias tuberosa, in Passiflora edulis $f$. flavicarpa (Negreiros et al., 2006), in Pseudobombax grandiflorum (J. C. Lopes, Matheus, Correa, \& Silva, 2008), in Schinus terebinthifolius (Vitória et al., 2018), in Mimosa ophthalmocentra (Leite, Nogueira, Freitas, Leite, \& Guimarães, 2019), and in Inga striata
(Mata et al., 2013). Thus, it is evident that the germination of green seeds can vary according to the species.

The emergence percentage $(\mathrm{E})$ informs the total number of germinated seeds, however, it does not reflect how long it took for the seeds to reach this germination percentage. In this approach, the mean emergence time (t) gives a kinetic point of view for $E$, providing information on how long it took for a given seed lot to germinate, that is, it corresponds to the mean time needed for a set of seeds to germinate (Ferreira \& Borghetti, 2013).

Regarding the ESI, the treatments with seeds from ripe fruits harvested from the matrix and unscarified green fruit seeds had the highest values, not differing statistically from each other (T1: 0.85, T2: 0.73, and T6: 0.62). The lowest values, as occurred in the percentage of emergence, were for treatments 4 and 5. Although this index is expressed without a unit, it relates the number of germinated seeds per unit of time (Ferreira \& Borghetti, 2013), that is, the higher the ESI, the higher the emergence speed, which infers the vigor of the seed lot.

For $t$, it was observed that seeds with a mature and developed integument (treatments 3 and 4) had slower emergence than seeds from other maturation stages, with a mean time greater than 31 days. The lowest value of $t$ was observed for treatment 1 (23.17 days), which had the highest value for ESI. The $t$ is also related to seed vigor, as the high seed emergence rate occurred in a shorter time. Following this order, seeds from unripe fruits (treatments 5 and 6) and seeds from mature fruits harvested from the matrix (1 and 2) had the lowest $t$ values, not differing from each other. 
In the distribution of the relative daily frequencies of germination, differences were observed between seeds of different maturation stages. It can be seen in Figure 4, that in seeds from ripe fruits collected in the matrix, the germination peaks were distinct, occurring between the $20^{\text {th }}$ and $22^{\text {nd }}$ day for seeds under mechanical scarification (tract. 1) and for intact seeds (treat. 2) on the $24^{\text {th }}$ day, with the presented values of ESI and $t$, being better than those evaluated for treatment
1. In figure 4 , the germination peak was very accentuated on the $29^{\text {th }}$ day for treatment 4, maintaining a characteristic of a leptokurtic distribution, that is, when seed germination is more concentrated in a certain time interval. Differently, treatment 3 did not present a sharp germination peak, maintaining a distribution spread over time, characterizing a platykurtic distribution (Figure 4C). Treatments 5 and 6 had a similar germination peak, which occurred between the $26^{\text {th }}$ and $28^{\text {th }}$ days.
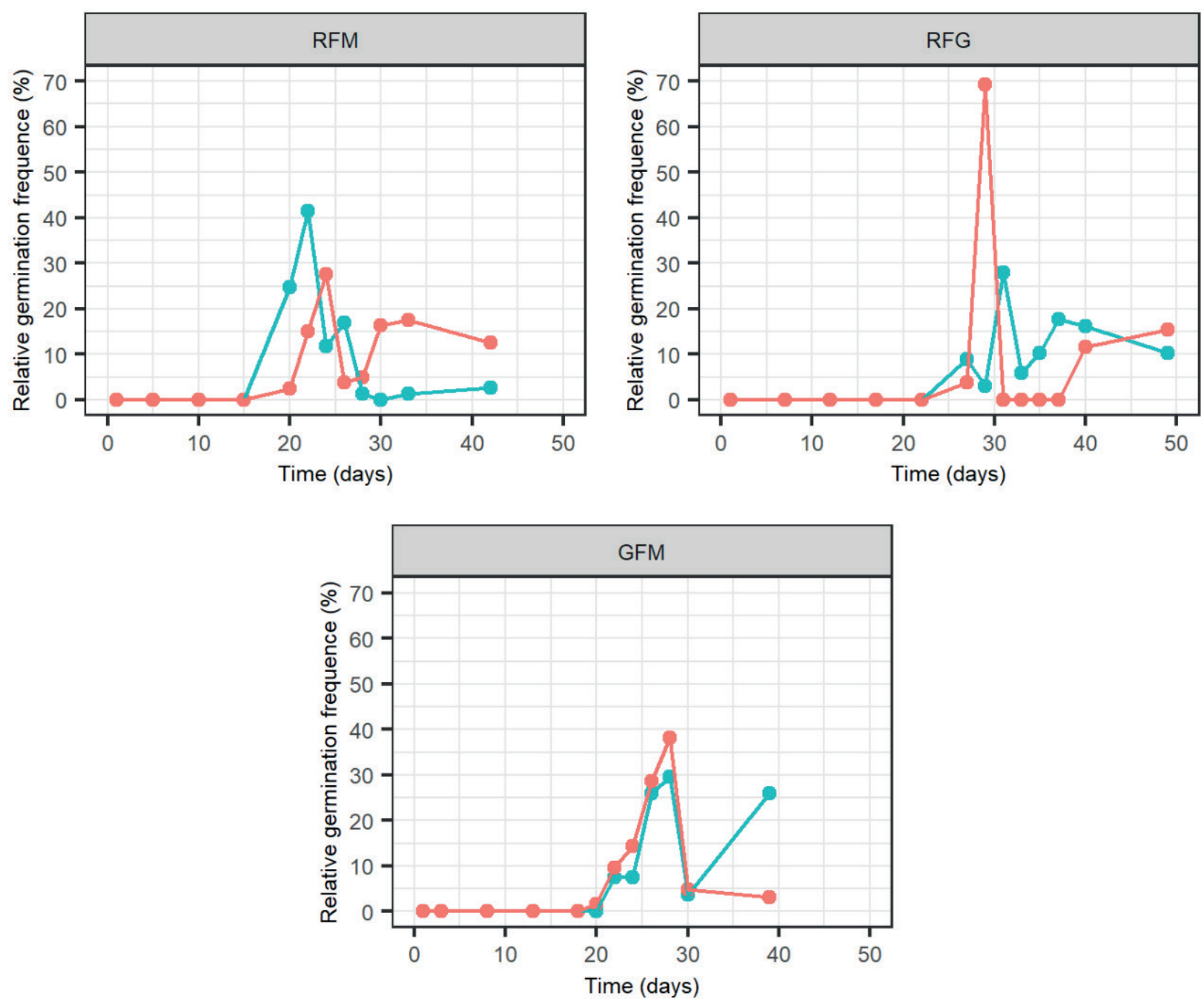

Figure 4. Relative Germination Frequency of scarified (blue) and intact (red) seeds of H. courbaril, clockwise, from ripe fruits collected from the matrix, from mature fruits collected from the ground, and from green fruits collected from the matrix. 
Thus, we found that the same species can present different patterns of germination frequency distribution according to the treatment received. These distribution arrangements are widely used to evaluate the effects of different treatments on the temporal distribution of seed germination (Ferreira \& Borghetti, 2013), enabling prediction or postulation of the germination behavior of a given species under certain conditions.

This difference in germination between fruits harvested from the matrix and from the ground may be related to the fact that mature seeds are not able to preserve their viability indefinitely, as their maturation involves processes that culminate in morphological, physiological, and biochemical alterations (Marcos, 2015). Wagner, Maciel, Radaelli and Guollo (2020) reported that when the storage environment is not suitable, the deterioration process is accelerated. When collected from the ground, the Jatobá seeds had probably already surpassed the physiological maturation point (when the seeds present maximum germination, vigor, and dry mass), which precedes the detachment of the fruit from the plant. Also with regard to seeds from green fruits, Marcos (2015) pointed out that most species have the ability to germinate well before reaching physiological maturity; however, the highest germinations are reached close to the maximum accumulation of dry matter.

Figure 5 shows the values obtained for the morphological determinations of the Jatobá seedlings. Regarding the root length, we found that treatments 4 (ripe fruit collected from the ground with non-scarified seeds) and 6 (green fruit collected from the matrix with seeds without scarification) obtained the highest values $(10.89$ and $10.18 \mathrm{~cm}$, respectively). Lorenzetti et al. (2018) found similar values of root development with seeds of Caesalpinia peltophoroides at different maturation stages.

Seed maturation influenced the leaf area of the seedlings, with a higher value for treatment 1, with $83.173 \mathrm{~cm}^{2}$ (Figure 6). Green seeds, on the other hand, had zero or very low values (Figure $6 \mathrm{E}-\mathrm{F}$ ), presenting slower leaf development until the end of the experiment, although no unevenness in germination was noted. According to Marcos (2015), the reduction in vigor implies an increase in the period necessary for the emergence and a reduction in seedling growth, as observed in the current study. 
A)

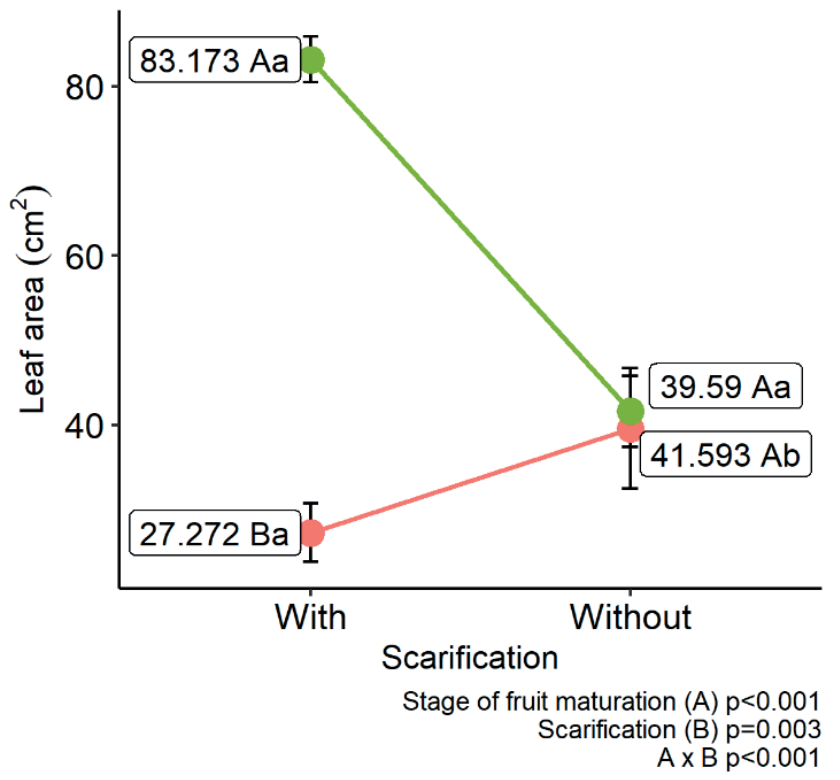

B)

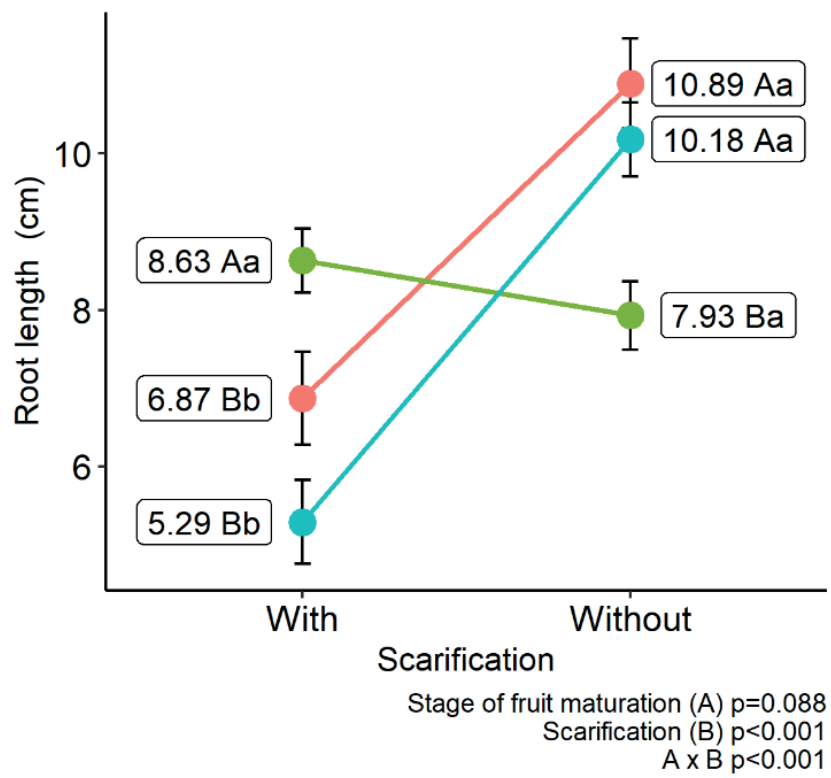

C)

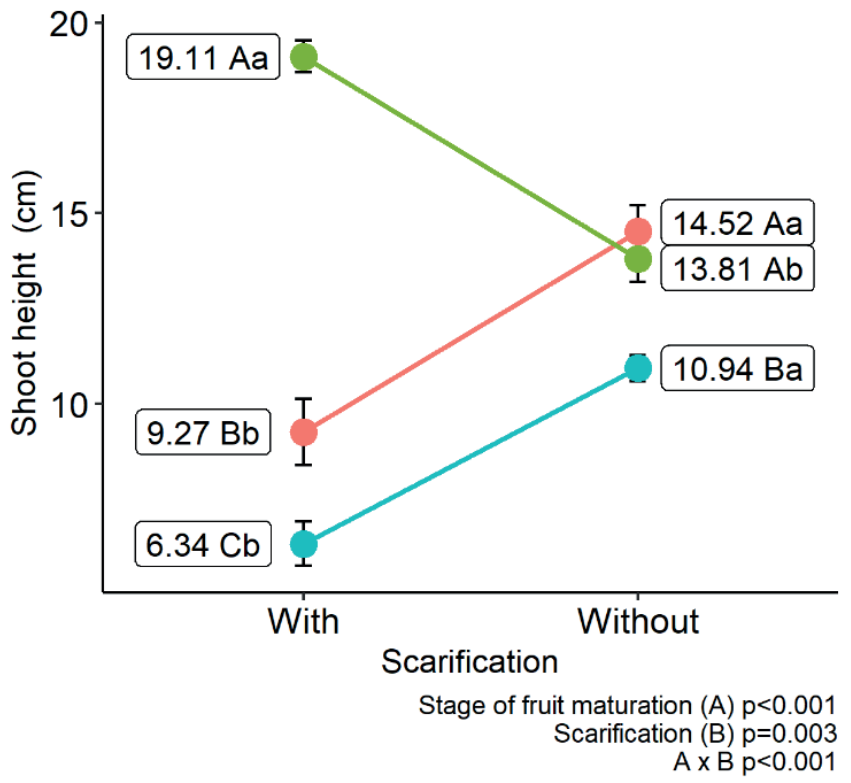

Figure 5. Shoot height $(\mathrm{SH})$, root length $(\mathrm{RL})$, and leaf area $(\mathrm{LA})$ of $H$. courbaril seedlings from seeds at different maturation stages.

*Means followed by letters of the same lowercase letter horizontally and uppercase vertically do not differ, according to the Tukey test at $5 \%$. LA CV $=30.74 \%$, Root Length CV $=19.38 \%$ and Height $\mathrm{CV}=15.67 \%$ Where: RFM - Ripe fruits harvested from the matrix (treatments 1 and 2), RFG - Ripe fruits collected from the ground (treatments 3 and 4), GFM -Green fruits collected from the matrix (treatments 5 and 6). 


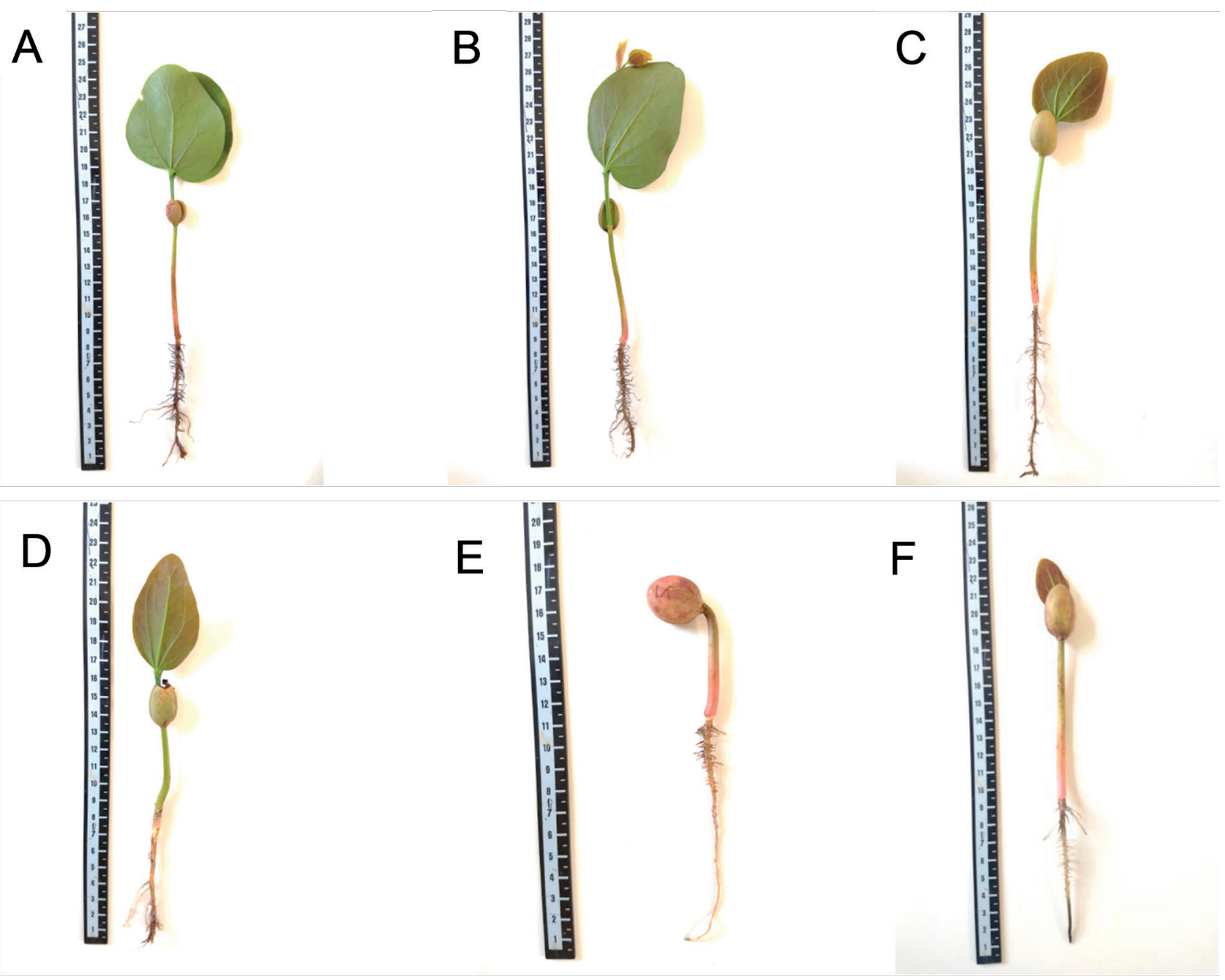

Figure 6. Development of $H$. courbaril seedlings from unscarified $(A)$ and scarified $(B)$ seeds from mature fruits harvested from the matrix; from unscarified (C) and scarified (D) seeds from ripe fruits collected from the ground; and from unscarified $(E)$ and scarified $(F)$ seeds from green fruits collected from the matrix.

With respect to treatment 4 , the fact that the seeds had a period of rest in the soil after detachment from the matrix proved to be advantageous, as this period promoted a gradual reduction in the degree of moisture of the seeds, which resulted in seeds with the capacity to develop and the formation of seedlings with adequate root and aerial systems.
For treatment 6, it is possible that the high levels of gibberellin stimulated the alphaamylase enzyme and other enzymes that promote hydrolysis of the reserve material, necessary for root growth (Antunes, Picolotto, Vignolo, \& Gonçalves, 2012). The same was not evidenced for treatment 5 , as scarification was harmful to the germination of green seeds and consequent seedling formation. 
Treatment 1 presented an average shoot height value of $19.11 \mathrm{~cm}$, being $27.73 \%$ higher than treatment 2, 51.5\% higher than treatment 3 , and $66.18 \%$ higher than treatment 5. This result demonstrates the high vigor of the seeds, as well as the fact that they reached higher values of \% E and ESI, and lower t. As evidenced by Mata et al. (2013) green seeds of Inga striata presented lower shoot development values when compared to mature seeds.

\section{Conclusions}

Jatobá seeds from different maturation stages are able to germinate.

Seeds from ripe fruits harvested from the matrix present greater vigor, as they show a higher percentage of emergence, higher emergence speed index, shorter average emergence time, and seedlings with a larger leaf area and longer shoot length.

Intact green seeds are recommended for sowing and seedling production, as they do not require pre-germination treatment and have a favorable emergence percentage, however seedling development is slow, which implies longer nursery time.

Seeds from fruits harvested from the ground require the help of a method to overcome tegumentary dormancy.

\section{References}

Alonso, J. M., Leles, P. S. S., Silveira, T. B., Fo., Mesquita, C. A. B., Pereira, M. L., Sales, J. A. S., Jr., \& Silva, C. D. O. (2014). Avaliação da diversidade de espécies nativas produzidas nos viveiros florestais do estado do Rio de Janeiro. Floresta, 44(3), 369-380. doi: 10.5380/rf.v44i3.31910

Antunes, L. E. C., Picolotto, L., Vignolo, G. K., \& Goncalves, M. A. (2012). Influência do substrato, tamanho de sementes e maturação de frutos na formação de mudas de pitangueira. Revista Brasileira de Fruticultura, 34(4), 1216-1223. doi: 10.1590/S0100-29452012000400031.

Barbosa, J. M., Rodrigues, M. A., Barbério, M., \& Araujo, A. C. F. B. (2015). Maturação de sementes de espécies florestais tropicais. In F. C. M. Pinã-Rodrigues, M. B. Figliolia, \& A. Silva (Eds.), Sementes florestais tropicais: da ecologia à produção (pp.180189). Londrina: Associação Brasileira de Tecnologia de Sementes - ABRATES.

Cabral, E. M. S., Castilho, R. M. M., \& Pagliarini, M. K. (2015). Germinação de sementes e desenvolvimento de mudas de Jatobá (Hymenaea courbaril L. var. Stilbocarpa). Revista Eletrônica Thesis, 23(1), 16-28.

Carvalho, N. M., \& Nakagawa, J. (2000). Sementes: ciência, tecnologia e produção (4a ed.). Jaboticabal: FUNEP.

Carvalho, N. M., \& Nakagawa, J. (2012). Sementes: ciência, tecnologia e produção (5a ed.). Jaboticabal: FUNEP.

Carvalho, T. C., Oliveira d'Angelo, J. W., Scariot, G. N., Saes, L. A., Jr., \& Cuquel, F. L. (2014). Germinação de sementes de Physalis angulata L.: estádio de maturação do cálice e forma de armazenamento. Pesquisa Agropecuária Tropical, 44(4), 357-362.

Castro, R. D., Bradford, K. J., \& Hilhorst, H. W. M. (2004). Desenvolvimento de sementes e conteúdo de água. In A. G. Ferreira, \& F. Borghetti, (Eds.), Germinação: do básico 
ao aplicado (pp. 51-67). Porto Alegre: Artmed.

Coelho, T. B., \& Ribeiro, V. A. (2018). Superação de dormência em sementes de jatobá. Ipê Agronomic Journal, 2(1), 14-22.

Costa, N. D., Bruno, R. L. A., Souza, F. X., \& Lima, E. D. P. A. (2001). Efeito do estádio de maturação do fruto e do tempo de préembebição de endocarposna germinação de sementes de umbuzeiro (Spondias tuberosa Arr. Câm.). Revista Brasileira de Fruticultura, 23(3), 738-741. doi: 10.1590/ S0100-29452001000300060

Duarte, M. M., Paula, S. R. P., Ferreira, F. R. L., \& Nogueira, A. C. (2016). Morphological characterization of fruit, seed and seedling and germination of Hymenaea courbaril L. (Fabaceae) ('Jatobá'). Journal of Seed Science, 38(3), 204-211. doi: 10.1590/2317-1545v38n3159734

Ferreira, A. G., \& Borghetti, F. (2013). Germinação - do básico ao aplicado. Porto Alegre: Artmed.

Gazzoni, D. L., Cattelan, A. J., \& Nogueira, M. A. (2019). O aumento da produção brasileira de soja representa uma ameaça para a floresta amazônica? (Documentos, 418). Londrina: EMBRAPA Soja- Empresa Brasileira de Pesquisa Agropecuária.

Hirano, E., \& Possamai, E. (2008). Estádio de maturação do fruto e germinação de sementes de três espécies de Lauraceae. Scientia Agraria, 9(2), 219-223. doi: 10. 5380/rsa.v9i2.11006

Labouriau, L. G., \& Valadares, M. E. B. (1976). On the germination of seeds Calotropis procera (Ait.) Ait.f. Anais da Academia Brasileira de Ciências, 48(2), 263-284.
Leite, M. S., Nogueira, N. W., Freitas, R. M. O., Leite, T. S., \& Guimarães, P. P. (2019). Maturação fisiológica e dormência em sementes de jurema-de-embira (Mimosa ophthalmocentra). Advances in Forestry Science, 6(2), 645-650. doi: 10.34062/afs. v6i2.7823

Loose, E. B., \& Balbé, A. D. (2020). Cobertura ambiental durante a pandemia no Brasil e em Portugal: explorando crises e (des)conexões. Chasqui, Revista Latinoamericana de Comunicación, 1(144), 47-68. doi: 10.16921/chasqui.v0i 144.4282

Lopes, A. W. P., Seleguini, A., Boliani, A. C., \& Côrrea, L. D. S. (2009). Estádio de maturação do fruto e uso do ácido giberélico na germinação de sementes de mamoeiro. Pesquisa Agropecuária Tropical, 39(4) 278-284.

Lopes, J. C., Matheus, M. T., Corrêa, N. B., \& Silva, D. P. (2008). Germinação de sementes de embiruçu (Pseudobombax grandiflorum (Cav.) A. Robyns) em diferentes estádios de maturação e substratos. Floresta, 38(2), 331-337. doi: 10.5380/rf.v38i2.11628

Lorenzetti, E., Carvalho, J. C., Souza, A. K. P., Queiroz, S. B., Belmonte, C., \& Malavasi, M. M. (2018). Determinação da maturidade fisiológica de Caesalpinia peltophoroides Benth. pela coloração de sementes. Scientia Agraria Paranaensis, 17(2), 231235.

Lorenzi, H. (2020). Árvores brasileiras - manual de identificação e cultivo de plantas arbóreas nativas do Brasil (Vol. 8). Nova Odessa: Editora Plantarum.

Maguire, J. D. (1962). Speeds of germinationaid selection and evaluation for seedling 
emergence and vigor. Crop Science, 2(2), 176-177. doi: 10.2135/cropsci1962.0011 $183 \times 000200020033 x$

Marcos, J., Fo. (2015). Fisiologia de sementes de plantas cultivadas. Londrina: Associação Brasileira de Tecnologia de Sementes - ABRATES.

Mata, M. F., Silva, K. B., Bruno, R. D. L. A., Felix L. P., Medeiros, S., Fo., \& Alves, E. U. (2013). Maturação fisiológica de sementes de ingazeiro (Inga striata) Benth. Semina: Ciências Agrárias, 34(2), 549-565. doi: 10.5433/1679-0359.2013v34n2p549

Ministério da Agricultura, Pecuária e Abastecimento (2009). Regras para análise de sementes. Brasília: MAPA/ACS.

Mojena, P. A., Barreto, M. R. (2021). Danos em frutos e sementes de Hymenaea courbaril L. por Rhinochenus stigma (Linneu 1764). Ensaios e Ciência, 25(1), 62-65. doi: 10.17921/1415-6938.2021 v25n1p62-65

Müller, E. M., Gibbert, P., Binotto, T., Kaiser, D. K., \& Bortolini, M. F. (2016). Maturação e dormência em sementes de Peltophorum dubium (Spreng) Taub. de diferentes árvores matrizes. Iheringia Série Botânica, 71(3), 222-229.

Munsell, A. H. (1952). Munsell Color Charts for plant tissues. Baltimore, Maryland: Munssel Color Company.

Nascimento, M. P. S. C. B., \& Oliveira, M. E. A. (1999). Quebra da dormência de sementes de quatro leguminosas arbóreas. Acta Botânica Brasilica, 2(13), 129-137. doi: 10.1590/S0102-33061999000200002

Negreiros, J. R. S., Wagner, A., Jr., Álvares, V. S., Silva, J. O. C., Nunes, E. S., Alexandre, R. S., Pimentel, L. D., \& Bruckner, C. H. (2006).
Influência do estádio de maturação e do armazenamento pós-colheita na germinação e desenvolvimento inicial do maracujazeiro-amarelo. Revista Brasileira de Fruticultura, 28(1), 21-24. doi: 10.1590/ S0100-29452006000100009

Nogueira, A. C., \& Medeiros, A. C. S. (2007). Coleta de sementes florestais nativas. (Circular Técnica). Colombo, PR: EMBRAPA

Pagliarini, M. K., Castilho, R. M. M., Nasser, F. A. D. C.M.,\&Alves, M.C.(2016). Tratamentosprégerminativos e substratos na germinação de sementes e biometria de plântulas de Hymenaea courbaril L. var. Stilbocarpa. Cultura Agronômica: Revista de Ciências Agronômicas, 25(1), 39-54. doi: 10.3292 9/2446-8355.2016v25n1p39-54

Pereira, S. R., Giraldelli, G. R., Laura, V. A., \& Souza, A. L. (2011). Tamanho de frutos e de sementes e sua influência na germinação de jatobá-do-cerrado (Hymenaea stigonocarpa var. stigonocarpa Mart. ex Hayne, Leguminosae - Caesalpinoideae). Revista Brasileira de Sementes, 33(1), 141-148. doi: 10.1590/S0101-31222011 000100016

Popinigis, F. (1985). Fisiologia da semente. Brasília: Editora Sília.

Regnier, L. D. L. P. (2020). Morphological integration between seeds and seedlings of Hymenaea courbaril. bioRxiv, 1-20, doi: 10.1101/2020.04.10.036178

Sampaio, M. F., Couto, S. R., Silva, C. A., Silva, A. C. A., Silva, A. A. S. S., \& Teixeira, A. L. (2015). Influência de diferentes substratos associados a métodos de superação de dormência na germinação e emergência de sementes de jatobá (Hymenaea courbaril L.). Revista Farociência, 2(1), 1127. doi: 10.36703/farociencia.v3i1.94 
Santos, J. C. C., Silva, D. M. R., Costa, R. N., Santos, S. A. S., Silva, L. K. S., \& Silva, J. V. (2019). Biometria de frutos e sementes e tratamentos prégerminativos em sementes de Hymenaea courbaril. Revista em Agronegócio e Meio Ambiente, 12(3), 957-979. doi: 10.17765/2176-9168.2019v12n3p957979

Silva, B. M. S., \& Cesarino, F. (2016). Germinação de sementes e emergência de plântulas de jutaí (Hymenaea parvifolia Huber.). Revista Brasileira de Plantas Medicinais, 18(1), 256-263. doi: 10.1590/1983-084X/ 15178

Souza, P. F., Santana, R. C., Fernandes, J. S. C., Oliveira, L. F. R., Machado, E. L. M., Nery, M. C., \& Oliveira, M. L. R. (2015). Germinação e crescimento inicial entre matrizes de duas espécies do gênero Hymenaea. Floresta e Ambiente, 22(4), 532-540. doi: 10.1590/2179-8087.067613

The Economist Newspaper (2019). Deathwatch for the Amazon. London: The Economist Newspaper Ltd. and the Economist Group.
Vitória, R. Z., Oliveira, F. D. T. G., Posse, S. C. P., Arantes, S. D., Schmildt, O., Viana, A., \& Barros, B. L. A. (2018). Qualidade fisiológica de sementes de aroeira em função da maturação dos frutos sob diferentes temperaturas de germinação. Nucleus, 15(2), 575-582. doi: 10.3738/1982.2278.2870

Wagner, A., Jr., Maciel, E. C. J., Radaelli, J. C., \& Guollo, K. (2020). Conservação de sementes nos frutos de pitangueira: estádio de maturação, embalagem alternativas e períodos de armazenamento. Acta Iguazu, 9(3), 1-8. doi: 10.48075/actaiguaz.v9i3.23576

Weisse, M., \& Goldman, L. (2019). Mundo perde área do tamanho da Bélgica em florestas tropicais primárias em 2018. Porto Alegre: Global Forest Watch. Recuperado de https://wribrasil.org.br/pt/blog/2020/06/ perdemos-um-campo-de-futebolde-floresta-tropical-primaria-cada-6segundos-em-2019 
